\title{
Impact of COVID-19 Pandemic towards Common Neglected Tropical Diseases among Indigenous Group in Malaysia
}

Mehru Nisha ( $\nabla$ mehrunisha@unikl.edu.my )

Universiti Kuala Lumpur https://orcid.org/0000-0003-2083-4267

Muhammad Alif Naim

Universiti Kuala Lumpur

Fabian Davamani

International Medical University

\section{Short Report}

Keywords: COVID-19, STH, NTDs, Indigenous community

Posted Date: December 8th, 2020

DOl: https://doi.org/10.21203/rs.3.rs-120974/v1

License: (c) (1) This work is licensed under a Creative Commons Attribution 4.0 International License.

Read Full License 


\section{Abstract}

The coronavirus disease 2019 is a pandemic which heavily affected all walks of around the world. Whilst all people are affected could be from to job losses, increase in poverty, sudden death of family member or loved ones and so many others, the indigenous communities in Malaysia do face severity of the Covid 19 pandemic effect. As being the minority community with lack of proper income, lack of education and incapable of adjusting themselves to new norm and living in areas with high prevalence of disease for the poor, like neglected tropical diseases- the overall impact of Covid 19 showed inequalities for the Indigenous (Orang Asli) community in Malaysia. Here we discuss on some of the challenges faced by Orang Asli community in Malaysia and how the pandemic hampered neglected tropical diseases like STHs infection monitoring in Malaysia.

\section{Background}

Neglected tropical diseases (NTDs) is defined as a variety of communicable diseases that is in existence among minority population, tribes or counties without adequate sanitation, poverty, living nearby habitant which are prone for infectious vectors or close contact with domesticated stray animals. The effective control measures that have shown disease improvement and control are via public education approaches, drug intervention, disease monitoring, and vector control [1]. In Malaysia, the most common NTDs that still exist in rural and aborigine tribe (Orang Asli) is soil-transmitted helminthiasis (STHs), mainly due to the poor living conditions and hygiene issues [2]. Since the STHs infection specifically targets a certain minority group, the only way where they get treated for having clinical symptoms like stomach cramps, anemia, etc. is from the rural clinics near their villages in Malaysia [3,4]. The education campaign which involves activities like hand hygiene campaign, sanitation campaign, and prevalence studies are commonly performed by researchers usually involving universities, colleges, or NGOs [5].

The coronavirus disease as we know emerged from Wuhan, China at trend before it spread vigorously across the globe. As reported by WHO, total cases till now are more than $54,611,015$ active cases, 1,322,317 deaths, and almost 220 countries are affected worldwide [6].

The coronavirus disease 2019 (COVID-19), however, had arrived in Malaysia, as early as 25 January 2020, while initially, the spread of the virus was well contained with the number of cases involved in the first wave limited to only 22, a sudden spike in cases, unfortunately, appeared at the end of March following a mass gathering involving 15,000 persons. Nearly 2000 positive cases eventually emerged from that single cluster, and the total count of infected individuals currently was above 6000 as of 27 April 2020 taken together all 13 states and the Federal Territory. Since May 18, 2020, various types of movements control orders were imposed by the government to control COVID-19 transmission [7].

The Orang Asli community comprises of eighteen ethnic groups and their population throughout Peninsular Malaysia totals around 178,000 . They live in environments with poor sanitation, and lack of knowledge in hygiene practice, they are exposed to high risk of infectious diseases, and live in poverty. 
Most of the Orang Asli community is dependent on the forest for planting, firewood gathering, and hunting and lead a simple life. The key government body which oversees the Orang Asli community affairs is JAKOA (Jabatan Kemajuan Orang Asli), Malaysia. [8, 9].

Since the emergence of COVID-19 in Malaysia, reports have shown many Orang Asli villages fled into the forest and blocked their villages from outsiders to protect their communities. The fear of COVID-19 became intense among the Orang Asli when a three-year-old boy from a village outside Cameron Highlands tested positive.Despite the government's endless efforts to reach all walks of the community in Malaysia, the minority group of the Orang Asli community has its challenges. It could be due to their cultural beliefs, geographic location, low level of education, fear and poverty $[10,11,12]$.

\section{Impact of lockdown and Movements Control Orders (MCO) to Malaysian}

The Malaysian government like other nations has introduced lockdown and movement control measures (MCO) as a crucial step to stop the spread of the virus, however human-to-human transmission occurred and much details about the virus remained unknown [13]. Since this is a novel viral strain, there has been lots of panicking, unable to comprehend the new norms like scanning QR code in each place, wearing the mask, using hand sanitizer, and some misleading information from social media on COVID-19 [14].

Next, the MCO has affected Malaysia's economy, especially in the tourism sector, airlines, and the entertainment sector. Some companies made their employees working from home, and some workers have had to stop working. Despite these challenges, some NGOs in Malaysia have been giving tremendous help to the poor, Orang Asli, homeless, and those jobless subjects. They have been providing food, protective masks, setting disinfections booth, etc. to all the affected people and the frontlines [15], and helping to educate citizens on COVID-19 [16].

\section{Impact of Movements Control Orders (MCO) to Orang Asli and Challenges in Monitoring STHs Infection}

The Orang Asli are the most affected community due to the COVID-19 pandemic. Being vulnerable to infectious disease due to their environmental conditions where they dwell, this community was received some consideration from the government and NGOs. Many of them work as daily wages lost their job, some fled to the forest for survival and their kids could not continue their school lessons as they could not cope with online classes and internet issues [17].

For the researchers who have been working closely monitoring the prevalence of STHs in these villages, all their activities were also disrupted which are listed as follows: -

1. The Deworming program need to be rescheduled. 
2. For those who are undergoing deworming treatment, their response to the treatment needs to be repeated if it exceeds one month, three months, or six months.

3. Periodic education campaign monitoring their hygiene activity was halted as the common hall was used to store donated food items and essentials.

4. Post MCO, some of the villagers were confused and fearful, were reluctant to cooperate in STHs survey suspecting the outsiders including the researcher may transmit the COVID-19 virus.

\section{Conclusion}

In summary, COVID-19 has taken so much attention and other diseases may have changed to be neglected, example STHs are common among Orang Asli in Malaysia. As this population is so vulnerable to this infection, efforts to control STHs need to be continued as usual following the new norm. The researcher and NGOs need to gain back their trust from the villagers to eradicate STHs infection. It may be debatable that the severity of STHs may not be so rampant as COVID-19 or any other diseases, however, considering the long-term impact of STHs on children and older folks, essential preventative measures need to be continued. Compromising and neglecting STHs infection among Orang Asli in Malaysia, will give enduring consequences to all the efforts placed by the researchers and health workers all these years may have some overall impact in the near future.

\section{Abbreviations}

NTDs: Neglected tropical diseases; STHs: Soil-transmitted helminths; MCO: Movements Control Orders; NGO: Non-governmental organization; WHO: World Health Organization; JAKOA: Jabatan Kemajuan Orang Asli; QR: Quick Response; COVID-19: Coronavirus disease 2019

\section{Declarations}

\section{Acknowledgements}

We acknowledge Orang Asli villagers especially in Perkampungan Orang Asli, Semenyih Malaysia Besides, we would like to thank National Health Commission of Malaysia for coordinating data collection for patients with COVID-19. We thank all health workers around the world for fighting this global pandemic.

\section{Authors' contributions}

Mehru Nisha conceived the idea; Muhammad Alif Naim and Fabian Davamani contributed to the writing and revisions. The author(s) read and approved the final manuscript.

\section{Funding}




\section{Availability of data and materials}

All data were obtained from the website of the National Health Commission of Malaysia with open access.

\section{Ethics approval and consent to participate}

This manuscript does not involve a research protocol requiring approval by the relevant institutional review board or ethics committee.

\section{Consent for publication}

Written informed consent for publication was obtained from all authors.

\section{Competing interests}

Mehru Nisha, Muhammad Alif Naim and Fabian Davamani declare no conflicts of interest.

\section{Author details}

${ }^{1}$ Universiti Kuala Lumpur, Institute of Medical Science Technology (MESTECH), 43000, Kajang, Selangor, Malaysia. ${ }^{2}$ International Medical University (IMU), No.126, Jalan Jalil Perkasa 19, Bukit Jalil, 57000, Kuala Lumpur, Malaysia

\section{References}

1. World Health Organization. Neglected Tropical Diseases.[Internet]Available at https://www.who.int/neglected_diseases/diseases/en/ (assessed 11th November 2020).

2. International Association for Medical Assistance for Travelers (IAMAT). [Internet] Available at https://www.iamat.org/country/malaysia/risk/intestinal-parasites-soil-transmitted-helminths\# (assessed 15th November 2020).

3. Rajoo Y, Ambu S, Lim YA, Rajoo K, Tey SC, Lu CW, Ngui R. Neglected Intestinal Parasites, Malnutrition and Associated Key Factors: A Population Based Cross-Sectional Study among Indigenous Communities in Sarawak, Malaysia. PLoS One. 2017;12:e0170174.

4. Ngui R, Ishak S, Chuen CS, Mahmud R, Lim YAL. Prevalence and risk factors of intestinal parasitism in rural and remote West Malaysia. PLoS Negl Trop Dis. 2011; 5:e974. doi: 
10.1371/journal.pntd.0000974 PMID: 21390157.

5. Alasil SM, Abdullah KA. An Epidemiological Review on Emerging and Re-Emerging Parasitic Infectious Diseases in Malaysia. The Open Microbiology Journal. 2019;13:112-20.

6. World Health Organization. Neglected Tropical Diseases. [Internet]. Available at https://www.who.int/emergencies/diseases/novel-coronavirus-2019.(assessed 17th November 2020).

7. Malaysia confirms first cases of coronavirus infection. Reuters [Internet]. Available at https://www.reuters.com/article/china-health-malaysia/malaysia-confirms-firstcases-of-coronavirusinfection-idUSL4N29U03A (assessed on April 7th 2020).

8. World Directories of Minorities and Indigenous People. [Internet] Available at https://minorityrights.org/minorities/orang-asli/ (assessed on 15th November 2020).

9. Khor GL, Shariff ZM. Do not neglect the indigenous peoples when reporting health and nutrition issues of the socio-economically disadvantaged populations in Malaysia. BMC Public Health. 2019;19(1):1685.

10. Bhagavathula A, Aldhaleei W, Rahmani J, Mahabadi M, Bandari D. 2020. Novel Coronavirus (COVID19) Knowledge and Perceptions: A Survey of Healthcare Workers. British Medical Journal.

11. Bunyan J. (16 March 2020). "PM: Malaysia under movement control order from Wed until March 31, all shops closed except for essential services". The Malay Mail. Archived from the original on 16 March 2020. Retrieved 16 March 2020.

12. Tang A (16 March 2020). "Malaysia announces movement control order after spike in Covid-19 cases (updated)". The Star. Archived from the original on 16 March 2020. Retrieved 18 March 2020.

13. Cao J, Tu W-J, Cheng W, Yu L, Liu Y-K, Hu Xet al. Clinical features and short-term outcomes of 102 patients with corona virus disease 2019 in Wuhan, China. Clin Infect Dis. 2020; ciaa243. https://doi.org/10.1093/cid/ciaa243 PMID: 32239127.

14. Mohamad E, Azlan AA. COVID-19 and communication planning for health emergencies. J Komun Malays J Commun. 2020;36(1):1-2.

15. Bernama C: Health Ministry beefs up screening at entry points into Malaysia. Bernama; 2020 Retrieved from https://www.theedgemarkets.com/ article/coronavirus-health-ministry-beefsscreening-entry-points-malaysia [Accessed 1 April 2020].

16. The Star. NGO educates public on disease. The Star; 2020 Retrieved from https:// www.thestar.com.my/metro/metro-news/2020/03/16/ngo-educates-public-on-disease [Accessed 31 March 2020].

17. CNN. International. Edition. Isolated and short of supplies, Malaysia's indigenous groups depend on aid to ride out movement control order. https:// [ Accessed 17th April 2020]. 